\title{
AN OVERVIEW OF TECHNOLOGY TRANSFER AS A REGULATORY ASPECT
}

\author{
G. M. PAVITHRA, MANORANJITH, S. NAGALAKSHMI*
}

Department of Pharmaceutics, Sri Ramachandra Faculty of Pharmacy, SRIHER(DU), Porur, Chennai 600116

*Email: nagalakshmimpharm@gmail.com

Received: 21 Oct 2020, Revised and Accepted: 28 Dec 2020

\begin{abstract}
Technology Transfer is fundamental and crucial to the drug development process for new drug products. The great decision is based on that factor in which the concept or process is advanced from research and development-oriented scheme to aimed towards the commercialization of the drug. The transfer could also be said to achieve success if the receiving section and the transferee can efficiently use the technology for profit. The achievement relies upon an understanding of the process or the capability to predict exactly the future prospects of a process. The main intention of this review article is to study the Regulatory aspects of technology transfer. This review article is mainly focused on the Consequence of technology transfer, the purpose for technology transfer in industries, barriers concerned with technology transfer, classification regarding technology transfer, facets of technology transfer, and steps among technology transferThis review was carried out by systematic searches of data integrity in relevant ICH, WHO, and US guidelines, published articles, reviews and abstracts in Google scholar, Pubmed, Science direct, Embase, Web of science of articles up to 2020 .
\end{abstract}

Keywords: Technology transfer, Pharmaceutical industry, WHO guidelines on technology transfer, ICH guidelines

(C) 2021 The Authors. Published by Innovare Academic Sciences Pvt Ltd. This is an open access article under the CC BY license (https://creativecommons.org/licenses/by/4.0/) DOI: https://dx.doi.org/10.22159/ijap.2021v13i2.40067. Journal homepage: https://innovareacademics.in/journals/index.php/ijap

\section{INTRODUCTION}

The terminology "Technology Transfer is the manner of interchange of technology and the invention from one area to a different area [1]. Across the pharmaceutical industry technology transfer states that the processes related to the fortunate movement of drug discovery to development and finally full-size promotion [2].

The consequence of technology transfer in the pharmaceutical industry

- For the Transfer of technology from R and D to manufacturing site clear information is mandatory.

- To accentuate information on the transfer technology of already available products among various manufacturing areas.

- This is required to enlighten particular procedures for technology transfer and contribute to continuous technology transfer.

- To establish an association between research institutes and profitable organizations [3].

\section{Purpose of technology transfer}

1. Inadequacy of manufacturing extent: The technology introducer might have its own manufacturing equipment that is applicable to small scale operation and large-scale manufacturing operations.

2. Shortage of resources to discharge product commercially: For conducting the early stage analysis like animal studies and toxicology studies the inventor must-have resources. But for performing clinical studies the resources are not available.

3. Deficiency of distribution and marketing competence: The inventor would completely establish a technology and obtained product registrations and regulatory approvals.

4. Application in various fields: To create an extra income the inventor may transfer the technology to someone else to use in another field that varies from the already applied field $[4,5]$.

\section{Obstacles of technology transfer}

The Obstacles confronted in technology transfer as follows:-

- Lack of a persistent framework for the understanding of the technology concept.
- Absence of procedures for receiving technology transfer in developing countries.

- In the progress of technology transfer, there is a lack of bilateral benefits.

- Unavailability of the persistent framework for analysis and evaluation of technology.

- Ergonomic aspects are failed to integrate into technology transfer.

- Lack of scrutiny to environmental and assessment of technological consequences.

- The feasibility study of technology transfer is limiting money evaluation.

- Misjudgment of the concept of technology usefulness.

- In the technology transfer process presence of ethical issues $[6,7]$.

Goals of technology transfer

- Technology transfer is an advantageous step in the development cycle to the commercial production of drug products.

- All the collected information is used as the grounds for the process qualification and continuous improvement of the product and manufacturing control strategy.

- The change of the data like the process, analytical data, or product between development and manufacturing plant.

- Various parameters and processes are controlled to justify the accepted parameters throughout the development $[8,9]$.

\section{Classification of technology transfer}

Technology transfer is classified into two types by Mansfield they are:

1. Vertical transfer begins with preliminary research ending with clinical research to the manufacturing of new drug products.

2. Horizontal transfer means the development and the application of technology utilized in one area, context, or institution to a different area, context, or institution [10].

According to Sounder's (1990) classification, vertical technology transfer is the progress of moving technology from one phase to 
another phase. vertical technology transfer is otherwise called internal technology transfer. Horizontal technology transfer is possible to transfer of technology at any stage of the lifecycle. Horizontal technology transfer is otherwise called external technology transfer [11].

Steenhuis (2002) categorized technology transfer into Material transfer, Capacity transfer, and Design transfer.

- The transfer of new material or products is denoted as material transfer.

- Various types of instructions or guidelines are transferred to meet the numerous requirements of the product is called a Capacity transfer.

- For improving the manufacturing of the product various designs and blueprints are transferred this is denoted as design transfer [12].

\section{Steps in technology transfer}

Technology transfer is defined as the procedure for the transfer of information and technology fundamental to the production of drug products. The development of a new drug undergoes many stages. The transformation of a pharmaceutical prototype towards a profitable product required the participation of a variety of individuals. Appropriate care should be taken to assure the quality of the product. During the early phase development, various parameters are considered such as critical and non-critical parameters, excipient availability, equipment, and production environment. There are numerous steps that encompass technology transfer. Technology transfer flow in pharmaceutical industry is in fig. 1 [13]. All methods for testing a given product, ingredient, or cleaning sample should be provided. If it is deemed unnecessary to qualify the method in the Receiving Unit, the justification should be documented. Table 1 describes the various types of tests like assay, sterility, dissolution is transferred from technology receiving site for different types of formulations.
Technology

Developer (R\&D lab)

Technology receiving

site

Feasibility study

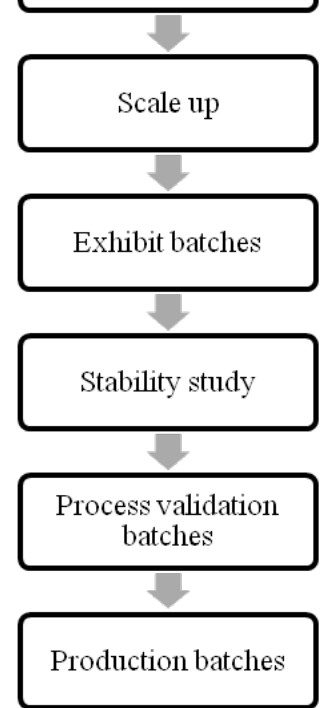

Fig. 1: Technology transfer flow in the pharmaceutical industry [15]

Table 1: API and dosage form tests to be transferred

\begin{tabular}{|c|c|c|c|c|c|c|c|}
\hline \multirow[t]{2}{*}{ Tests } & \multirow[t]{2}{*}{ API } & \multicolumn{6}{|l|}{ Dosage form } \\
\hline & & Solid doses & Parenterals & Inhalation & Semi-solids & Suspensions & Transdermal \\
\hline Assay & $\mathrm{X}$ & $\mathrm{X}$ & $\mathrm{X}$ & $\mathrm{X}$ & $\mathrm{X}$ & $\mathrm{X}$ & $\mathrm{X}$ \\
\hline Content Uniformity & & $\mathrm{X}$ & $\mathrm{X}$ & $\mathrm{X}$ & $X$ & $\mathrm{X}$ & $\mathrm{X}$ \\
\hline Impurities & $\mathrm{X}$ & $\mathrm{X}$ & $\mathrm{X}$ & $\mathrm{X}$ & $\mathrm{X}$ & $\mathrm{X}$ & $\mathrm{X}$ \\
\hline Dissolution & & $\mathrm{X}$ & & & & $\mathrm{X}$ & \\
\hline Identification & $\mathrm{X}$ & $\mathrm{X}$ & $\mathrm{X}$ & $\mathrm{X}$ & $\mathrm{X}$ & $\mathrm{X}$ & $\mathrm{X}$ \\
\hline Cleaning Verification & $\mathrm{X}$ & $\mathrm{X}$ & $\mathrm{X}$ & $\mathrm{X}$ & $\mathrm{X}$ & $\mathrm{X}$ & $\mathrm{X}$ \\
\hline Cleaning Verification & $\mathrm{X}$ & $\mathrm{X}$ & $\mathrm{X}$ & $\mathrm{X}$ & $\mathrm{X}$ & $\mathrm{X}$ & $\mathrm{X}$ \\
\hline Dose Delivery & & & & $\mathrm{X}$ & & & \\
\hline Sterility & & & $\mathrm{X}$ & & & & $\mathrm{X}$ \\
\hline
\end{tabular}

\section{Development of technology by research and development}

a. Design of procedure and choosing of excipients by research and development

The $\mathrm{R}$ and $\mathrm{D}$ department is responsible for selecting materials and design procedures for the development of the drug.

\section{b. Determination of Specification and Quality by $R$ and $D$}

The quality of the drug product must conform to the specifications of an innovator product that should be examined by the R and D Department. For manufacturing product and innovator products, various stability studies are performed to confirm the specifications [16].

\section{Technology transfer from randd to production}

The $\mathrm{R}$ and $\mathrm{D}$ department is implemented the Technology transfer dossier that contains all the detailed information about the formulation and the drug product includes:

\section{Master formula card}

MFC comprises a drug product name together with its MFC number, effective date, the strength of the formulation, generic name of the drug product, page number, and shelf life of the product [17].

\section{Master packaging card}

Master Packaging Card is consisting of information regarding the material used for packaging of the product, packaging type, shelf life of the packaging, and stability of the packaging.

\section{Master formula}

It describes the instructions for the manufacturing and formulation of the product. Manufacturing instructions provide the objective of environmental conditions and dosage form development.

\section{Specifications and standard test procedure}

It is used to know about the active ingredients and excipients profile of the product, specification, in-process parameters, and finished product information [18].

\section{Production phase (Optimization and production)}

\section{a. Validation studies}

After conducting numerous validation studies production is started based on the manufacturing formula. The R and D department is responsible for the validation like process validation, cleaning validation, and performance qualification. 


\section{b. Scale-up for production}

This deals with the transferring of technology across the development of the processes and drug products. During the development of the process, it is necessary to investigate the production environment. Various operations are performed during the formulation of the solid dosage form. Technology transfer is implemented before the production begins [19].

\section{c. Considerations of different parameters for scale-up}

Different parameters like innovation, flexibility, cost, product quality is considered for successful technology transfer. Good communication is an important factor for successful formulation and process transfer.

\section{d. Selection of method}

Based on the data from $\mathrm{R}$ and $\mathrm{D}$ the method for batch fabrication was chosen. The critical steps in technology transfer are granulation, blending, compression, and coating [20].

\section{Technology transfer documentation}

The Document includes details of technology transfer towards transferred parties and transferring. From Research and Development to production every step must be documented, and all commitments ought to be rectified. The Quality Assurance department is responsible for the approval of documentation for technology transfer.

\section{A. Development report}

The $\mathrm{R}$ and $\mathrm{D}$ department is responsible for documentation. The Development Report is clarifying the quality design for drug substances, specifications, and test methods. For approval, this report is not necessary. The Development Report encompasses:

(1) Data from the initial development stage to the final approval.

(2) Raw materials and components information.

(3) Manufacturing methods design.

(4) Changes are made in the vital processes and parameters.

(5) Specifications and test strategies for drug substances.

(6) The validity of the specification range for the dissolution test and contents impurity.

(7) Reports are checked [21]

\section{B. Technology transfer plan}

A technology transfer plan consists of complete procedures for individual transfer of technology, details regarding technology to be transferred, agenda for technology transfer, and decision criteria for technology transfer. Before the implementation of the transfer, the transferring party must prepare the plan.

\section{Report}

If the data is taken into the technology transfer plan only the technology transfer is completed. The data are assessed to confirm that the agreed criteria are met. Both transferred parties and transferring parties must document the report [22].

\section{Factors affecting technology transfer}

7 factors are challenging towards establishing prerequisites for pharmaceutical technology transfers.

(1) A feasible and reachable market

(2) Suitable capital markets

(3) Quality of the relationship between industry and the government

(4) Appreciable economic governance, stability
(5) Accessibility of skilled employee

(6) Adequate regulation

(7) Understandable development precedence [23]

\section{Facets of technology transfer}

The transfer of technology has occurred especially in the subsequent ways:
A. Government laboratory to private sector firms
B. Between private sector firms of the same country
C. From academia to private sector firms
D. Academia, government, and industry collaborations

\section{A. Govt. laboratory to private firms}

The Government labs will receive financial assistance and funds from the government for the conducting of research work and technology passes the private firms. So, this type is more advantageous.

\section{B. Among private firms of the same country}

Due to a lack of financial resources or insufficient information this type of technology transfer is takes place. The private firm establishes the technology is compensated by different firms.

\section{From academics to private firms}

The academic firm develops specific technology and is accessible to various private sectors. By the cooperation of private sectors with organizations, money is often saved.

\section{Among academy, govt. and private firms}

The government furnishes funds to the academic organizations for promoting technology this will be transmitted to the industry [24].

\section{Who guidelines on transfer of technology}

Throughout the life cycle of the majority of medicines like the development of drug products, production, and launching into the market in all phases the processes are transferred to an alternate site.

This WHO guideline will be applicable to both manufacturing of active pharmaceutical ingredients, production, and packaging of finished pharmaceutical products, and carrying out analytical testing [25].

Transfer of technology needs a plan and documentation utilizing the qualified and well-experienced person functioning in the quality system, with evidence of data regarding all areas of development, manufacturing, and quality control. Generally, there's the unit managed the process, a receiving unit, and a sending unit [26]. Fig. 2 describes the WHO Guidelines on technology transfer.

The WHO guidelines address the following areas at the receiving unit (RU) and sending unit (SU)

- Transfer of development processes and Manufacturing of the drug product, packaging, and cleaning.

- Transfer of methods of analysis for quality control, and quality assurance.

- Competencies evaluation and training.

- Evaluation of premises and equipment.

- Documentation of all the data.

- Organization and control of the technology transfer.

Qualification and validation of all the processes [27]. 


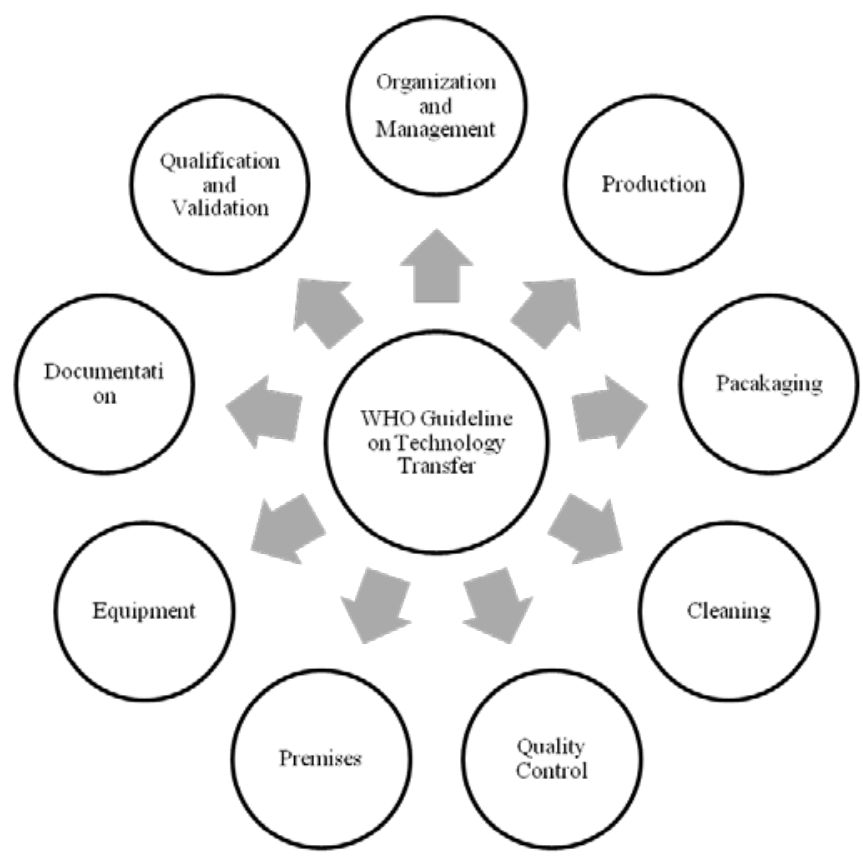

Fig. 2: WHO guidelines on technology transfer

\section{Transfer protocol}

The technology transfer protocol must list the intentional consecutive steps of the transfer. The transfer protocol should encompass:

- Objectives

- Scope

- Key personnel and their duties.

- A parallel assessment of materials, processes, and equipment.

- The technology transfer steps with documented proof that every single crucial step had been sufficiently accomplished earlier than the subsequent commences.

- Identity of important control measures.

- For analytical methods design and acceptance criteria
- Details on the pilot batches, qualification batches, and process validation.

- Change control procedure for any process discrepancies confronted.

- Evaluation of the end-product

- Provisions for retaining samples of active ingredients, intermediates, and finished drug products, and details on reference samples where appropriate.

- Conclusion includes signed-off approval by the project manager [28].

\section{Role of ich guidelines in technology transfer}

Technology transfer comprises of knowledge transfer, science, and risk-based principles inclusive of ICH Q8, Q9, Q10, Q11, and proficient processes to satisfy evolving commercial needs. The role of various ICH guidelines is providing in fig. 3 .

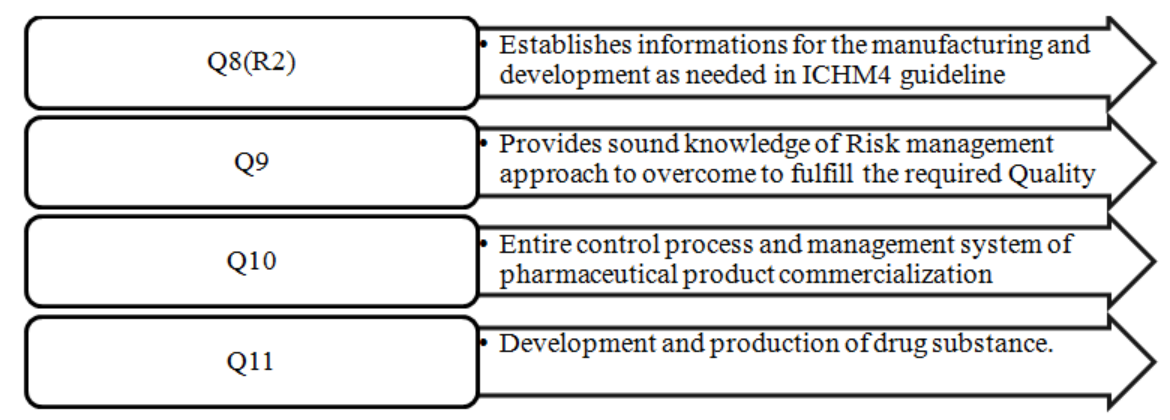

Fig. 3: Role of ICH guidelines

This determines the requirements for profitable Technology Transfer and offers guidance for the conduct of technology transfer, which might be separately tailored, relying on the sort and scope of the transfer [29].

\section{ICH Q10 guidelines on technology transfers}

According to ICH Q10 guidelines, "The intention of technology transfer operations is to transfer process, and product information among the development and manufacturing sites, and within production sites to attain product realization. This information is the basis for the manufacturing of the product, monitoring strategies, process validation, and ongoing persistent improvement."

To guarantee a successful technology transfer, pharmaceutical companies ought to create a collaborative improvement team must have the required qualification, knowledge, and skills to affect the 
transfer, originate a written controlling method to concentrate attention on crucial points in the process and equipment, review the process for inputs/outputs that might affect the quality of the product [30].

\section{FDA technology portfolio}

FDA's Technology Transfer assists the transfer of these technologies to the private firms via licensing and patenting of these developments. Therefore, new medicinal products like vaccines, counterfeit drug detection, manufacturing, and food pathogen detection systems are developed and make accessible on the market.

Over the past few years alone, FDA researchers are developed and reported around 20 patentable inventions every year. FDA retains over six hundred invention assets that exemplify over 100 unique technologies [31]. Article 101 of the Treaty on the Functioning of the EU to technology transfer agreements. Technology transfer agreements relate to the licensing of technology rights in which the licensor allows the licensee to create the licensed technology rights for the manufacturing of goods or products. The requirements set out in these guidelines should be utilized in the light of the conditions particular to every case. These guidelines do not include mechanical application. Every case needs to be evaluated on its own circumstances and these guidelines are applied flexibly, and reasonably [32].

\section{CONCLUSION}

Transfer of information and technologies are necessary to meet the quality of the drug during production. Technology transfer might be investigated fortunately in case a receiving section can constantly reproduce the process. The three fundamental points to be discussed throughout the technology transfer are the plan, the persons concerned, and the production process. Technology Transfer offers a possibility to decrease the cost of drug discovery and development thus pharmaceutical enterprises seek technology transfer opportunities as it rates of failure, reduce risk, and costs. A collaborative work by the technology team leads to better outcomes initial and consistent runs resulting in the prior license, earliest launch, and an increased market share.

\section{SOURCES}

ICH Website, WHO website, Pharmatutor, Good Practice Guide: Technology Transfer, Google Scholar

\section{FUNDING}

Nil

\section{AUTHORS CONTRIBUTIONS}

All the authors have contributed equally.

\section{CONFLICTS OF INTERESTS}

Declared none

\section{REFERENCES}

1. Ramanathan K. An overview of technology transfer and technology transfer models. Available from: http://tto.boun.edu.tr/files/1383812118_An\%20overview\%2 0of\%20TT\%20and\%20TT\%20Models.pdf. [Last accessed on 03 Oct 2020]

2. Allamneni Y, Chary PD, Kumar SC, Rao VB. Technology transfer process in pharmaceutical industry: an overview | PharmaTutor; $2020 . \quad$ Available from: https://www.pharmatutor.org/articles/overview-oftechnology-transfer-in-pharmaceutical-industry. [Last accessed on 03 Oct 2020]

3. Talokar SS, Vakhariya RR. Technology a buzz word in pharma world. Asian JPharm Sci 2017;7:18-22.

4. Amneet K, Sharma OP, Jatinder D. Technology transfer in pharmaceutical industry. Int J Curr Pharm Res 2013;5:16-8.

5. Bhusan B, Nautiyal U, Kumar S, Bakar A. Technology transfer in pharmaceutical industry: a review. Int J Pharm Med Res 2014;2:94-9.
6. Rani SS, Rao BM, Ramaro P, Kumar S. Technology transfermodels and mechanism. Int J Mech Eng Technol 2018;9:971-82.

7. John RM. Technology transfer in pharmaceutical industry. Pharma Innovation J 2017;6:235-40.

8. Misar SN, Bhurghate AV, Sisodia JS, Gaikwad SK, Patil HB. Technology transfer: a paradigm for industry. Int J Pure Appl Biosci 2014;2:221-8.

9. Waghmare YS, Mahaparale SP. The important role of technology transfer in pharmaceutical industry-a review. World J Pharm Res 2017;6:310-29.

10. Mansfield, Edwin. International technology transfer: forms, resource requirements, and policies. Am Econ Rev 1975;65:372-6.

11. Souder WE, Nashar AS, Padmanathan V. A guide to the best technology transfer practices. J Technol Transf 1990;15:1-2.

12. Steenhuis HJ, de Boer SJ. Differentiating between types of technology transfer: the technology building. Int J Technol Transfer Commercialisation 2002;1:187-200.

13. Mohite PB, Sangle SV. Technology transfer in pharmaceutical industry-a review. Int J Adv Pharm Res 2017;6:1-7.

14. Good Practice Guide: Technology Transfer (Third Edition). Available from: https://guidance-docs.ispe.org/cdn1590534466328/Good-Practice-Guide-Technology-TransferThird-Edition/. [Last accessed on 01 Dec 2020]

15. Manu C, Gupta V. Review on technology transfer in pharmaceutical industry. Int J Pharm Qual 2016;7:7-14.

16. Amanjeet, Aggarwal G. Technology transfer in pharmaceutical industry: a discussion. Int J Pharma Bio Sci 2010;1:1-5.

17. Pagar S, Khivansara A, Pagar P, Gandhi M, Jondhale S. Review article on technology transfer. Int J Pure Appl 2014;2:145-53.

18. Sajid A, Vinay P, Chander S. Technology transfer in pharmaceuticals. Int Res J Pharm 2012;3:43-8.

19. Manral M, Prashar B, Sheikh Y. Technology transfer in pharmaceutical industry: facts and steps involved. Am J Pharma Tech Res 2012;2:73-82.

20. Wani R, Kashid A, Ghatge A, Shaoo S. An overview of technology transfer in industry. Int J Adv Pharm 2017;6:103-9.

21. Ojha A, Mini. Technology transfer: a technique for providing novelistic platform to develop quality and efficiency in pharma sector. Eur J Biomed Pharm Sci 2014;1:49-77.

22. Patil R. Constituents and factors of technology transfer in pharmaceutical industry-learn about gmp: accredited online life science training courses [Internet]. Learn about gmp: Accredited online life science training courses; 2011. Available from: https://learnaboutgmp.com/good-manufacturing-practicescgmp/constituents-and-factors-of-technology-transfer-inpharmaceutical-industry/. [Last accessed on 03 Oct 2020]

23. Alam MS, Ahmad J. Pharmaceutical technology transfer: an overview. Int J Pharm Sci 2013;4:1.

24. Janodia M, Sreedhar D, Ligade VS, Udupa N. Facets of technology transfer: a perspective of pharmaceutical industry. J Intellect Prop Rights 2008;13:28-34.

25. Good manufacturing practices for sterile pharmaceutical products In: WHO Expert Committee on Specifications for Pharmaceutical Preparations. Thirty sixth report. Geneva, World Health Organization; 1992.

26. Quality assurance of pharmaceuticals; 2006. Available from: https://www.who.int/medicines/areas/quality_safety/quality assurance/QualityAssurancePharmVol2.pdf. [Last accessed on 03 Oct 2020]

27. Annex 7 WHO guidelines on transfer of technology in pharmaceutical manufacturing; 2011. Available from: https://www.who.int/medicines/areas/quality_safety/quality assurance/TransferTechnologyPharmaceuticalManufacturingT RS961Annex7.pdf. [Last accessed on 03 Oct 2020]

28. ICH Harmonized Tripartite Guideline. Pharmaceutical development. Q8 (2R). As revised in August 2009. Geneva, ICH Secretariat; 2009. Available from: http://www.ich.org/lOB/media/MEDIA4986.pdf. [Last accessed on 03 Oct 2020]

29. Suthar R, Shah JS. Review on technology transfer as a regulatory aspect with inclusion of ICH guidelines. Asian J Pharm Technol Innov 2017;5:32-40. 
30. Fong N. Principles of technology transfer; 2016. Available from: https://www.outsourcedpharma.com/doc/principles-oftechnology-transfer-0001. [Last accessed on 03 Oct 2020]

31. FDA Technology Transfer Program. U. S. Food and Drug Administration; 2017. Available from: https://www.fda.gov/ science-research/fda-technology-transfer-program. [Last accessed on 01 Dec 2020]

32. Guidelines on the application of Article 101 of the Treaty on the Functioning of the European Union to technology transfer agreements. European Union; 2014. 